Comparative Philosophy Volume 13, No. 1 (2022): 139-159

Open Access / ISSN 2151-6014 / www.comparativephilosophy.org

https://doi.org/10.31979/2151-6014(2022).130110

CONSTRUCTIVE-ENGAGEMENT DIALOGUE

PHILOSOPHICAL INTERPRETATION: MODERN BUDDHISM

AUTHOR MEETS CRITICS:

\title{
COSMOPOLITANISM, CREOLIZATION, AND NON-EXCEPTIONALIST BUDDHIST MODERNISMS: ON EVAN THOMPSON'S WHY I AM NOT A BUDDHIST
}

\author{
YARRAN HOMINH \& A. MINH NGUYEN
}

\begin{abstract}
In his recent book, Why I Am Not a Buddhist, Evan Thompson argues that inter-tradition or cross-cultural philosophical dialogue ought to be governed by cosmopolitan conversational norms that do not subsume any one tradition's deep commitments under those of any other tradition, but rather bring those commitments into the discussion so that they can be challenged and defended. He argues on this basis for the application of a deeply contextualist and historicist interpretive methodology to Buddhist texts, concepts, and theories in dialogue with philosophy and contemporary cognitive sciences. Buddhist modernism, in eschewing that deeply contextualist and historicist methodology, falls short of those cosmopolitan commitments. We argue that Thompson's cosmopolitan commitments do not mandate the deeply contextualist and historicist methodology he recommends. As an alternative, we propose a creolizing methodology that finds value in mixing, reinterpreting, and reinventing cultural traditions and other forms of belonging to address the complex problems the world faces. We suggest that such a creolizing methodology can be found in other forms of Buddhist modernism than those Thompson criticizes. We provide, as two examples, the thought of the Chinese monk Taixu and the Vietnamese monk Thich Nhat Hanh.
\end{abstract}

Keywords: Buddhist exceptionalism, Buddhist modernism, contextualism, cosmopolitanism, creolization, Evan Thompson, historicism, individualism, interpretive methodology, Jane Anna Gordon, reductionism, science-religion dialogue, scientism, Taixu, Thich Nhat Hanh

Evan Thompson's recent book, Why I Am Not a Buddhist, is a provocative, insightful, and challenging critique of what he calls "Buddhist modernism" (Thompson 2020, 1),

HOMINH, YARRAN: Mellon Postdoctoral Fellow in Philosophy, Dartmouth College, USA. Email: yarran.d.k.hominh@dartmouth.edu

NGUYEN, A. MINH: Professor of Philosophy, Florida Gulf Coast University, USA. Email: atnguyen@fgcu.edu 
a broad religious, cultural, and intellectual movement that he regards as "the dominant strand of modern Buddhism" (Thompson 2020, 1). Like Bertrand Russell's "Why I Am Not a Christian" (2004) and similarly named texts like Kancha Ilaiah's Why I Am Not a Hindu (1996) and Ibn Warraq's Why I Am Not a Muslim (1995), Thompson's Why I Am Not a Buddhist is, among other things, a critique of the role and place of the Buddhist modernist movement in today's world, especially in Europe and North America (Kachru 2021, 29).

Unlike those texts, however, Thompson's target is not Buddhism in its entirety. Nor is his critique purely negative or antagonistic. He does not assert, for instance, that Buddhism has no place in the contemporary world. Rather, Thompson's critique is conceived and formulated from the perspective of a "good friend to Buddhism" (Thompson 2020, 2, 189), one who wishes for Buddhism "to take its rightful place as a valuable contributor to a modern cosmopolitan community" (Thompson 2020, 2). Such a community deeply engages different religious, philosophical, literary, artistic, social, economic, political, and scientific traditions. Thompson himself has been a valuable contributor to these conversations between Buddhism, Western philosophy, and the cognitive and brain sciences, beginning with his influential co-authored book, The Embodied Mind: Cognitive Science and Human Experience (Varela, Thompson, and Rosch 2016), and then as part of the Mind and Life Institute over the last two decades.

Thompson's main argument is that Buddhism's contributions to a "modern cosmopolitan community" (Thompson 2020,2) are disserved by core assumptions and commitments of Buddhist modernism. If Buddhism is best to play its part in this cosmopolitan conversation - a conversation between contemporary science and various religious, philosophical, intellectual, and contemplative traditions - then it must question these assumptions and commitments, "destabilize" (Thompson 2020, $180,184)$ them, and ultimately repudiate them.

The two key terms in Thompson's argument are "Buddhist modernism" (Thompson $2020,1,172$ ) and "cosmopolitanism" (Thompson 2020, 165-89). In this commentary, we would like to raise questions about the scope of each term in reverse order. With respect to "cosmopolitanism", we ask whether the kind of deep historicist and contextualist interpretation of the classical Buddhist texts and traditions is the only way in which Buddhism could satisfy Thompson's demand for a properly cosmopolitan Buddhism. In particular, we invite Thompson's thoughts on the possibilities of "creolized" Buddhist thought. By "creolization", we mean a modernist method of engaging with traditions conceived by political theorist Jane Anna Gordon (2014), among others. Drawing on the histories of Caribbean anti-colonial political thought, champions of this method propose that mixing, reinterpreting, and reinventing cultural traditions and other forms of belonging in light of specific challenges and opportunities can help us forge ways of thinking and living that are familiar but also novel and distinctive.

We suggest that this creolizing methodology coheres with the central features of Buddhist thought and Thompson's thought, including his views on the self and his (practical, not critical) philosophical methodology. Deploying certain contemporary 
modernist forms of Buddhism from China and Vietnam, we suggest further that there are directions of "moderate" Buddhist modernism that might be better contributors to cosmopolitan conversations than the forms that Thompson criticizes (the language of "moderation" here is drawn from Garfield 2021).

The line of thought we pursue here is not intended as a critique of Thompson's arguments against the neurological and essentialist forms of Buddhist modernism that are his stated target, arguments with which we are largely sympathetic. It is, rather, a response to Thompson's cosmopolitanism - the larger and more provocative philosophical and methodological position upon which his narrower critique restsand an attempt to outline further possibilities inspired by his arguments. We intend that response to be in the humanist and cosmopolitan spirit of Thompson's book and his body of work more generally. We have both learned an immense amount from engaging with Why I Am Not A Buddhist, and we hope that the line of inquiry pursued in this paper serves as a contribution to the kind of engaged philosophical and cosmopolitan conversation that Thompson's book so eloquently exemplifies.

\section{COSMOPOLITAN CONVERSATION AND BUDDHIST MODERNISM}

Thompson's critique of Buddhist modernism is that it undermines Buddhism's potential contributions to a wider cosmopolitan culture. Let us take those two central terms - "Buddhist modernism" and "cosmopolitanism"-in reverse order. What is cosmopolitanism, and why does Buddhist modernism fail to contribute properly to it?

Thompson follows Kwame Anthony Appiah (2007) in articulating a form of cosmopolitanism based on the model of conversation between traditions and between forms of life. ${ }^{1}$ Drawing on the work by Sheldon Pollock (2006) and others on the

\footnotetext{
${ }^{1}$ In Cosmopolitanism: Ethics in a World of Strangers, Appiah articulates and defends an attractive cosmopolitan position, which he dubs "partial" or "rooted" cosmopolitanism (Appiah 2007, xvii). Partial cosmopolitans "take sides neither with the nationalist who abandons all foreigners nor with the hardcore cosmopolitan who regards her friends and fellow citizens with icy impartiality" (Appiah 2007, xvi-xvii). Rooted cosmopolitans affirm that "loyalties and local allegiances ... determine who we are" and that "a creed that disdains partialities of kinfolk and community may have a past, but it has no future" (Appiah 2007, xviii). In accordance with Appiah's crisp formulation of cosmopolitanism as "universality plus difference" (Appiah 2007, 151), cosmopolitan virtues include concern for others on account of shared humanity and respect for legitimate differences in thought and action (Appiah 2007, xv), whereas cosmopolitan commitments include commitments to universal truth, tolerance, pluralism, and fallibilism (Appiah 2007, 144). Pluralism, he asserts, is the view that "there are many values worth living by and that you cannot live by all of them"; for pluralists, it is neither surprising nor undesirable that different people and different societies subscribe to different values (Appiah 2007, 144). Fallibilism, which Appiah also calls "epistemic humility", is the view that "our knowledge is imperfect, provisional, subject to revision in the face of new evidence"; knowing they do not have all the answers, fallibilists are humble enough to think they may learn from others (Appiah 2007, 144). See also Scheffler 1999. Appiah-style commitments to universal truth, tolerance, pluralism, and fallibilism (epistemic humility) share a strong family resemblance to confidence in reason, intellectual empathy, intellectual integrity, and intellectual humility as delineated by Richard Paul and Linda Elder in their celebrated model of critical thinking. See Paul 2008; Paul and Elder 2005; Paul and Elder 2009; and Elder and Paul 1998. See also Nguyen 2012 and Nguyen 2013.
} 
Sanskrit cosmopolis (Thompson 2020, 21, 51, 117, 170-172), which began around the start of the Common Era, Thompson conceives cosmopolitanism as marked descriptively by "processes and practices of transregional affiliation" (Thompson 2020, 172). These processes and practices, for Thompson, carry with them a normative commitment to respecting and engaging with the variety of particular human ways of living that are ways of instantiating our common humanity. Descriptively, this form of conversation across different communities and traditions - that is, conversation among individuals with ties or attachments to different communities and traditions - is both the process that constitutes cosmopolitan identities and the means by which cosmopolitanism as a practice generates insights and directions for inquiry. Normatively, this commitment to respecting and engaging with these other ways of living involves conversing with others in their full particularity. It is not enough that this particularity be merely expressed; cosmopolitan conversation, in Thompson's view, demands that the parties truly allow the other voices in that conversation to challenge and "destabilize" (Thompson 2020, 180, 184) their deepest commitments, including their "assumptions, positions, and arguments" (Thompson 2020, 77).

Thompson's cosmopolitanism is explicitly set against the strongly universalist European conception advocated by thinkers such as Hugo Grotius (1625) and Immanuel Kant (2006). In contrast to this universalist conception, predicated on the view that, in the end, we will settle on values and standards shareable by all, Thompson (again following Appiah 2007) holds that particular and different ways of living have value in themselves and are of interest in themselves because they are ways of being human. ${ }^{2}$ Cosmopolitan conversation does not have to end in agreement for it to be successful or fruitful. In Appiah's words, "it's enough that it helps people get used to one another" (Appiah 2007, 85; cited at Thompson 2020, 176).

Buddhist modernism falls short of these cosmopolitan commitments because [1] it holds (a modernist version of) Buddhism up as exceptional, either among other religions or in not "really" being a religion, insofar as [2] Buddhism is uniquely rational, according to a scientific (indeed, scientistic) standard of rationality. Buddhist modernism of the sort Thompson is criticizing - and Thompson fully accepts that there are other forms of Buddhist modernism and that he is not providing a definition of Buddhist modernism in these terms - is thus committed to what Thompson calls Buddhist exceptionalism. ${ }^{3}$ It is committed in particular to a reductionist and scientistic

\footnotetext{
${ }^{2}$ In the background of this cosmopolitanism is a humanism, expressed perhaps most aptly by the African-born Roman playwright Publius Terentius Afer, better known in English as Terence. Terence writes, "I am human: nothing human is alien to me" (Appiah 2007, 111).

${ }^{3}$ Thompson (2020 and 2021) uses the term "Buddhist modernism" in much the same way as McMahan (2008) does, which is to pick out an interrelated set of tendencies and themes in contemporary (largely) Euro-American Buddhist thought. The term is not intended as a definition or to specify a set of necessary or sufficient conditions for something (construed in the broadest possible manner) to be Buddhist modernist. Rather, it is meant to highlight some common and recognizable ideas from a complex and diverse tradition arising from the collision of modernism in its broadest and most pluralist sense and the varied histories of different Buddhist traditions. As he makes clear in his "Replies to Critics," especially his response to Velez de Cea 2021, Thompson takes Buddhist modernism not to have a "unique [ideological or doctrinal] essence", defined by a set of rules, tenets, theories, or principles, but rather to
} 
form of exceptionalism, one that arises from the turn-of-the-twentieth-century context in which many Buddhist reformers across the globe were attempting to make Buddhism into a "world religion". This process of reform, responding to (by resisting and by adapting elements of) the Christian and colonial context of the time, involved simultaneously challenging Christianity's claim to be the only truly "modern" religion by rendering Buddhism compatible with modern science and, as part of that challenge, absorbing elements of modern, largely Protestant and individualist, conceptions of religion (McMahan 2008, Ch. 3; Prothero 1996; Harding, Hori, and Soucy 2020; Lopez 2012, Ch. 2). ${ }^{4}$ In doing so, these Buddhist modernist reformers drew Buddhism into the orbit of a widespread and largely Westernized worldview.

One way to articulate Thompson's critique is to notice that Buddhist modernism, in his view, is deeply ironic. It purports to render Buddhism exceptional among other religions, yet it can treat Buddhism as exceptional only by subsuming it under a framework that privileges one particular form of scientific rationality over all other forms of engagement with the world. ${ }^{5}$ It falls short of properly cosmopolitan practice insofar as, in doing so, it occludes or at least downplays the rich resources that Buddhist traditions have for illuminating important philosophical and human questions, and thus not only damages Buddhism's competence to deal with these questions but also erodes Buddhism's capacity to challenge and destabilize key assumptions and positions championed by our dominant worldview.

These considerations raise one initial question: Is the problem with Buddhist exceptionalism merely that it is exceptionalist or that it is scientistically exceptionalist? Put differently, is the problem the general claim, to be fleshed out in specific ways in specific cases, that Buddhist modernists treat Buddhism as superior to other religions (or, in its superiority, as not "really" a religion)? Or is the problem the particular claim that the specific epistemic standards according to which it is supposedly superior are those that are part of the dominant worldview and (let us assume) largely shared by the other participants in the Buddhism-science conversations in which Thompson is particularly interested?

We think Thompson means the latter, even if he would also hold the former to be a problem. Let us outline some considerations in favor of that reading. If the former is the problem, and assuming that being uncosmopolitan is a barrier to engaging in cosmopolitan conversation (by analogy, to paraphrase Rawls 2001 and Rawls 2005 on reasonableness within a just and stable liberal democracy, one can't reason with the unreasonable), then the entry requirements for engaging in cosmopolitan conversation are very high. This is because presumably most people who hold a particular system of beliefs that is incompatible with other systems of beliefs tend to think theirs to be

be "a broad cultural movement having many variants ... [and] constituted by clusters of traits or properties", of which Buddhist modernist traits or properties there is, in general, "a frequency distribution" (Thompson 2021, 43). Cf. Lopez 2012.

${ }^{4}$ We leave aside the important political (read: nationalist and anti-colonial, though sometimes still imperialist) aspects of this process of modernization across Asia.

${ }^{5}$ See Ganeri 2021, 19-20 on the connection among scientism, Eurocentrism, and what he calls "European exceptionalism". 
superior to those others, just because it is, by their lights, true. So one might think the cosmopolitan entry requirements so high as to amount not only to fallibilism - the claim that one must take one's commitments to be revisable, which Thompson explicitly rejects as a logical or conceptual requirement of cosmopolitanism-but also to the stronger claim that one must, at least for the purposes of that conversation, no longer take one's beliefs, convictions, or understanding to be true (Thompson 2021, 47, in response to Guerrero 2021). ${ }^{6}$ For if one must think one's own tradition on par with others, then why believe it? ${ }^{7}$ And one presumably need not be a full ecumenicist to be a cosmopolitan. So exceptionalism in the general sense of believing one's religion to be superior in one way or another cannot be what Thompson means.

A more reasonable position to attribute to Thompson would be that one can believe in the superiority of one's religion in the sense that one thinks that "we've got it right" so long as the substantive beliefs that one thinks one has right are open to revision in light of the cosmopolitan conversation. If that is right, then general exceptionalism is not uncosmopolitan in the abstract or in a general way even if certain forms of exceptionalism are uncosmopolitan for specific reasons. So we are left with the particular claim. Scientistic exceptionalism is uncosmopolitan because we are specifically interested in the conversation between Buddhism and science, and because, within that conversation, there is really no potential to revise one's beliefs since the entire conversation is dominated by the one scientistic worldview. Going forward, therefore, we will read Thompson as criticizing scientistic exceptionalism in particular, where that critique is not simply an a priori or otherwise general attack, but a critique that focuses on the specific consequences that Buddhist exceptionalism of that sort has in present historical circumstances. ${ }^{8}$

How is this exceptionalism justified? Thompson points out and criticizes several interpretive strategies used by Buddhist modernists in service of their views, strategies that are part of the wider subsumption of Buddhist traditions under modern scientific rationalism. First, Buddhist modernists interpret key Buddhist ideas and concepts through a reductionist and scientistic worldview rather than understanding those features of Buddhist traditions from within the rich context of those traditions. For instance, "neural Buddhists" take notions like "no-self", "awakening", and "mindfulness" to be definable in terms of brain states or processes and supported by contemporary neuroscientific findings. Mindfulness meditation just is brain training; awakening just is a particular brain state (Thompson 2020,12). This method of interpretation isolates certain Buddhist concepts and lifts them out of the web of

\footnotetext{
6 "In any case, although my personal way of being cosmopolitanist is fallibilist, I would not make fallibilism a logical or conceptual requirement of cosmopolitanism." (Thompson 2021, 47)

${ }^{7} \mathrm{We}$ do not mean to deny that there are possible, and possibly satisfying, answers to this admittedly rhetorically phrased question. One may follow one's tradition because it is one's tradition or because, in a Jamesian fashion, one wills to believe.

${ }^{8}$ It is thus consistent for Thompson to think, whether he does or not, that the Buddhist modernist reformers at the turn of the twentieth century were quite cosmopolitan in developing their scientistic forms of Buddhism, for their purposes of (say) fostering a global Buddhism, resisting various Orientalist and imperialist conceptions of the "East", attempting to preserve or at least protect cultural traditions against outside influence, or whatever. Being "uncosmopolitan" is a context-bound criticism.
} 
concepts and practices in which they have meaning. "Awakening" no longer aims at nirvana; "suffering" is defined as a mental state and is therefore not understood ontologically as a fundamental structuring feature of the world; and so on.

Second, Buddhist modernists interpret key Buddhist ideas and concepts in an individualistic fashion that we can, as a shorthand, call "Protestant". This Protestant reading ignores the larger social, cultural, and religious practices and rituals (for example, traditions of textual exegesis, faith in rebirth and nirvana, and the social role of monastic orders) that give these ideas and concepts meaning. This Protestantism manifests itself in an interpretive strategy common to many modernist religious traditions (e.g., Salafist, Pentecostal, and Hindutva traditions): that of going back to what the Buddha (or any other central religious figure or text, whether Jesus Christ, the Prophet Muhammad, or the Hindu smritis) really said (McMahan 2008, Ch. 3, especially 65-9; for the use of "Protestant Buddhism", see Gombrich and Obeyesekere 1988 and Prothero 1996; Thompson opposes this strategy in Thompson 2020, 19-20).

Both of the above interpretive strategies abstract away from the complex and historically situated traditions and rituals that constitute much of religious practice in order to try to isolate the "core" of Buddhism that is its purported contribution to cosmopolitan conversation. And both strategies occlude what may be particularly unique about Buddhism by reading it through a common and widespread worldview, one that is scientistically rationalist and individualistic, thus undermining that contribution.

\section{COSMOPOLITANISM, CONVERSATION, CREOLIZATION}

With this summary of his critique in hand, let us now turn to our own critique of Thompson. First, let us ask: What is the relation between this process of interpretive abstraction and the subsumption of Buddhism under a scientistic and individualist worldview? To answer this, let us return to Thompson's vision of cosmopolitanism. His emphasis on conversation that takes seriously different traditions and their deep assumptions and commitments stands in contrast to conversation that takes as its starting point only one tradition and absorbs other viewpoints into the assumptions and ways of seeing the world characteristic of that tradition. We can say in this way that Thompson's conception of cosmopolitanism rests on a principle of non-imperialism. Imperialism in this sense occurs when one way of thinking imposes itself on another, thus preventing that other from being expressed.

With this principle in hand, we can say that the fundamental problem with Buddhist exceptionalism is that it is imperialistic: Buddhist exceptionalism imposes a modern scientistic framework on Buddhism. ${ }^{9}$ In turn, this non-imperialist principle grounds Thompson's insistence on deep historicism and contextualism, reading Buddhist ideas and concepts in their original (read: classical Indian and Tibetan) contexts. That

\footnotetext{
${ }^{9}$ This scientism, some have argued, was tied up with larger imperial projects in South and Southeast Asia and a historiography focusing on elite reimaginings of Buddhism. See Harris 2006. See also Abeysekara 2019 and the references in Harding, Hori, and Soucy 2020.
} 
historicism-cum-contextualism is a way of resisting the imposition of our modern scientistic, reductionist, and individualist worldview, through an interpretive process of abstraction and then recontextualization, onto those Buddhist ideas and concepts.

This reading of Thompson leads us to our main question: Does the principle of nonimperialism that underlies Thompson's cosmopolitanism imply the deep form of interpretive contextualism that he insists upon? ${ }^{10}$ We suggest not. There are other interpretive methodologies and ways of engaging with historical traditions that are nonimperialist and thus can contribute fruitfully to cosmopolitan conversation. ${ }^{11}$ And these alternative methodologies have been employed by forms of Buddhism that respond to modernity without being modernist in Thompson's sense of scientistically exceptionalist. Let us first outline one broad alternative methodology before examining how that methodology might apply in the case of Buddhism.

The alternative methodology we raise is that of "creolization". While "creolization" has a number of meanings and referents in various literatures, our own use follows that of Gordon (2014), who employs the term both descriptively and normatively. Descriptively, "creolization" refers to the development of new perspectives and practices by unequal and often opposed groups living "within relations marked by mundane dependency, antagonism, intimate and complex interpenetration" (Gordon $2014,10)$ through "recontextualization" (Gordon 2014, 10), "reinvention, resituating, and mistranslation" (Gordon 2014, 170) in "contexts of radical historical rupture" (Gordon 2014, 3). Normatively, creolization describes the generative potential for mutual transformation that may arise from taking such cases of descriptive creolization as a "methodological orientation toward the ... future" (Gordon 2014, 193).

We argue that creolization is a form of cosmopolitanism in Thompson's sense for two reasons. First, it focuses on, in Thompson's words, "processes ... of transregional affiliation" (Thompson 2020, 172) — what arises from interactions among differently located groups and ways of life. It is attentive to the particularities of those ways of life and the ways, not always conversational or on equal terms, in which they butt up against one another. This is cosmopolitan in Thompson's descriptive sense. ${ }^{12}$

\footnotetext{
${ }^{10}$ For a question along similar methodological lines, though not framed in terms of the non-imperialist principle, see Finnigan 2021. Finnigan questions whether the only form of encounter between Buddhism and science must seek transformation by emphasizing difference and challenging deep assumptions, or whether emphasizing points of similarity might not also be productive.

${ }^{11}$ As regards Appiah's cosmopolitanism, compare Jeffers 2013a, which Thompson (2020) references approvingly at 187 and 217. Thompson also follows the structure of Jeffers's early analysis of Nussbaum 1996 and Scheffler 1999 in the earlier parts of Chapter 6. Jeffers argues there and in other work, and here we can hear Thompson echoing him, that preservation of culture is a means of resisting imperialism. (Recall, for Jeffers, that "race" is a cultural notion. See Jeffers 2013b and Jeffers 2019.) We agree with Jeffers to the extent that this kind of preservation is one important means of resistance. But this provides a context-bound and strategic defense of cultural purity that is not fully at odds with the creolizing methodology we present in this paper.

${ }^{12}$ There is a panoply of terms close to "creolization", including "hybridity" and "syncretism". While there may be minor differences among the terms, perhaps in regard to geographical scope or connotation, for our purposes nothing much turns on which term one wants to use so long as the substance is retained. "Hybridity" carries some of the flavor of original purity - that of two distinct things that have been combined. And "creolization" may be wider than "syncretism" insofar as the latter has a particularly
} 
Second, creolization is cosmopolitan in a normative sense. Normatively, creolization seeks not merely to achieve some multiculturalist aggregation of these ways of life, one that leaves intact the commitments with which participants began, but also to transform those commitments and to form new, shared ones, "to rearticulate the world" (Gordon 2014, 3). Creolization not only looks to maintain or preserve already distinct ways of life, even with the intention of preserving them as resources for critiquing or enriching dominant ways of life, but also attempts to forge through mixture and hybridization genuinely new ways of engaging with the world in order to deal with the problems we face. ${ }^{13}$ In other words, creolization is normatively marked by a problem-addressing attitude (akin to pragmatism), which draws on all available cultural resources to create something that speaks to those problems. Creolization is anti-purity in the sense that it does not treat cultures, either descriptively or evaluatively, as pure or authentic such that departures from or changes to them result in their being impure or inauthentic. Importantly, this commitment to anti-purity is put explicitly in the service of anti-imperialist ends, both politically (in Gordon's original formulation) and interpretively (in ours). ${ }^{14}$

In addition to being a cosmopolitan view, creolization marks a particularly modernist form of sociocultural mixing. This is so not only because it occurs in situations of radical rupture, rootlessness, and intensification characteristic of modernity (the colonial encounter in the Caribbean, for example, though we might add Meiji-era Japan, ongoing Chinese influence in Vietnam, and the globalization of Zen in Brazil), but also because it responds to such situations by valuing the mixing, fragmentation, and "illicit blendings" that people in these situations construct (Gordon $2014,10,163,177)$. Creolization also constitutes a modernist process in the sense of embodying and embracing a "radically present- and future-oriented constructive ethos", not being held to tradition for tradition's sake (Gordon 2014, 200). Yet it is not fully unhistorical insofar as it seeks to understand the historical situations that give rise to particular creolizations. Strategically, it does not deny that there may be purposes served by traditionalist appeals to "preservation".

Creolization is, however, not deeply historicist in the way that Thompson's methodology seems to be. It does not insist that the meanings of concepts are limited by the contexts in which they were developed. Contexts change, swiftly as well as slowly, and radically as well as incrementally, and there is room not only for reinterpretation but also for reinvention so long as the reasons for that reinterpretation and reinvention are kept in view.

religious connotation and is mainly descriptive, lacking often that normative or methodological element essential to creolization. In addition, creolization has the benefit of carrying a stronger anti-imperialist connotation.

13 "Moving beyond dialogue of respectful difference, which none of us should denigrate, we instead explore creating ways in which otherwise fragmented accounts of shared political, physical, and geopolitical spaces could and do combine." (Gordon 2014, 163)

${ }^{14}$ Gordon $(2014,189 \mathrm{ff})$ argues that creolization occurs disciplinarily as well as culturally, her home discipline of comparative political theory serving as a key example. We think that this disciplinary creolization fits well with Thompson's own philosophical methodology, which draws liberally from hermeneutics, history, psychology, sociology, and other social sciences, as well as the natural sciences. 
One might raise two questions here. First, why is creolization appropriate for Buddhism? Second, what are the potential beneficial consequences of creolization for cosmopolitan conversation? Let us respond to these briefly.

Creolization is not an arbitrary methodology to apply to Buddhism for two reasons. The first is that, as a matter of historical fact, Buddhism is already heavily creolized. ${ }^{15}$ From the Sanskrit cosmopolis to Buddhism's spread across East and Southeast Asia and through the West, Buddhism has always mixed with the other traditions with which it has come into contact to form sometimes radically new and different Buddhisms. ${ }^{16}$

${ }^{15}$ The notion of creolization that we draw on here bears some surface similarities to the Buddhist (particularly Mahāyāna) notion of "skillful means" or upāya-kauśalya. That phrase refers to the multiple teachings of the Buddha and the bodhisattvas intended to bring beings to enlightenment. Those teachings are means (upāya) by which beings are brought to enlightenment. They are multiple and sometimes inconsistent because beings are in different circumstances, and teaching them may best involve drawing on or addressing specifically those circumstances. Skillful means serves the protreptic purpose of meeting beings where they are, with their particular attachments, sufferings, and aptitudes. So there is a surface similarity between skillful means and creolization insofar as both focus on differences in Buddhist traditions that result from purposeful mixings. And both notions have been taken up to define scholarly and interpretive methods that follow the practices themselves. Skillful means and creolization are not identical, however, for four reasons.

(1) They serve different ends. Creolization seeks "to rearticulate the world" (Gordon 2014, 3), to deal with a variety of urgent problems in contemporary life through that process of mixing. It serves cosmopolitan purposes. Skillful means serves the soteriological purpose of bringing beings to enlightenment. So processes of creolization may be forms of skillful means, but it is not necessary that they are.

(2) Relatedly, skillful means presupposes that there is a correct transcendent viewpoint, that of the Buddha or the bodhisattvas, that sets a hierarchy of means. Each means is to be superseded as beings reach closer to enlightenment (McGarrity 2009). Creolization imposes no such hierarchy and does not rely on any transcendent viewpoint.

(3) Skillful means carries with it (at least in its Mahāyāna usages) particular Buddhist commitments, such as a commitment to the existence of only a single vehicle for enlightenment. These commitments often serve a polemic purpose, for instance, in privileging the Mahāyāna (Great Vehicle) above other paths to enlightenment (e.g., in the second verse of the Lotus Sūtra). It is not apparent that these commitments are consistent with Thompson's views, whereas creolization, as a form of cosmopolitanism, seems closer to the ideas that he endorses.

(4) Skillful means is a broader category than creolization. It refers (e.g., in the third verse of the Lotus Sūtra, or the Skill in Means Sūtra) not only to the processes of mixing and adaptation that Buddhism has undergone, and the soteriological and protreptic purposes of these processes, but also to an overall style or outlook, a way of performing any action whatsoever as a means to enlightenment. In this larger meaning, skillful means has been taken to be definitive of (a particular form of) Buddhism (Pye 2003; Schroeder 2001; Federman 2009; Williams 2021).

We are indebted to Jeff Richey for raising this point with us.

${ }^{16}$ Thompson makes this point explicitly. It forms the basis for some of his arguments against Buddhist modernism's appeal to being the one true Buddhism. Consider the following passages:

(1) There is no one traditional Buddhism. Buddhism is an evolving tradition that has taken innumerable forms over the millennia in Asia and now in Europe and North America. (Thompson 2020, 19)

(2) Buddhist philosophy must be seen in the dialectical context of its engagement with the other South Asian philosophical traditions. Its lasting insights, analyses, and arguments -including the ones of value to us today in philosophy and cognitive science - are products of this larger dialectical encounter and are not the property of the Buddhist tradition alone. (Thompson 2020, 105) 
It has adopted Hindu deities into its pantheon in Sri Lanka and Myanmar; it has combined itself in Japan with Shinto conceptions of the spiritually enchanted natural world; it has informed and drawn on European conceptions of Romanticism to influence movements such as deep ecology and contemporary panentheisms; and everywhere it has merged with popular and folk religious practices. Richard Gombrich describes this as Buddhism's "accretive" tendency, though he interprets this tendency, through an essentialist lens, as one of lay Buddhists to add non-Buddhist religious practices onto an underlying pure (Theravāda) Buddhism (Gombrich 2009, 58). Creolization as an interpretive methodology thus fits with this historical tendency. ${ }^{17}$

Creolization also fits with key Buddhist doctrines of impermanence and interdependence (Tweed 2011; Vasquez 2008). Like selves, traditions do not have an essence and are not the worse for that. They have their existence in their encounters and engagements with other traditions, breaking apart, forming anew, in flux and change, in response to the needs and desires of peoples and institutions. So too creolization fits with Thompson's own views about the self, namely, that while there is no essential, substantive self, there is an ongoing emergent constructed and (self-)constructing self formed by different kinds of activity (Thompson 2014; Thompson 2020, Ch. 3). Similarly, while there is no "pure" or "essential" Buddhism, there is an ongoing process of constructing Buddhism(s) that serves, in better or worse ways, the interests and needs of people and other (institutional, organizational) actors.

Creolization thus descriptively fits Buddhist practice and key Buddhist tenets. What are the potential benefits of a creolizing methodology for cosmopolitan conversation? A fuller answer to this question is up to Buddhists and others who seek to build Buddhism as a vehicle for "an enlightened future the full dimensions of which [they] could not know" (Pittman 2001, 157). ${ }^{18}$ We will just outline here some relevant features of two forms of creolized Buddhist modernism, those of the Chinese monk Taixu (1890-1947) and the Vietnamese monk Thich Nhat Hanh (1926-). We use these as examples of a variety of Buddhist modernisms that engage in cosmopolitan exchange with other religious and scientific traditions.

(3) The idea of "authentic Buddhism," however, is unhelpful. Buddhism is a constantly evolving tradition that has taken numerous forms throughout its history. It's a missionary religion and has always been enmeshed in the economic systems of its home cultures. (Thompson 2020, 119-20)

(4) Buddhism helped to form and was formed by what Pollock calls the "Sanskrit cosmopolis," the "transregional culture-power sphere of Sanskrit." (Thompson 2020, 170)

(5) Buddhism from the beginning has been a missionary religion and constantly seeks expansion. So it continually evolves and takes on new cultural forms. Buddhist modernism is one of the latest iterations in Buddhism's ongoing transmission and transformation. (Thompson 2021, 42)

${ }^{17}$ For studies of this creolizing tendency in the global South, see Rocha 2005 and Clasquin-Johnson and Krüger 1999.

${ }^{18}$ We are here adopting a line from Pittman 2001 describing Chinese Buddhist modernist monk Taixu's conception of Mahāyāna Buddhism. Taixu, Pittman writes, was concerned with Buddhism's “portability into an enlightened future the full dimensions of which he could not know... Mahāyāna Buddhism was not a static place in which to remain; rather it was, quite literally, a 'great vehicle' (da sheng), a spiritual conveyance" (Pittman 2001, 157). 
These two Buddhist modernisms do not commit the interpretive errors that Thompson criticizes. They do not abstract away individual concepts from the larger metaphysical web of concepts and practices in which the individual concepts have their life, but rethink, in a connected fashion, large swaths of the web. They do not separate ideas from rituals and practices, but reappropriate and reinvent traditional rituals and practices for their own purposes. Those purposes are not simply "reducing stress and improving concentration" (Thompson 2020, 119) or other such limited things, but are soteriological and embedded in a larger metaphysics. That metaphysics, in turn, is neither a reductionist or materialist naturalism nor a simple supernaturalism, but a metaphysics that finds divinity in this world - a "liberal" naturalism, if you will, one not limited to the ontology of the objective sciences (Macarthur 2019). Thus, importantly, they are not exceptionalist in the scientistic sense. They do not subsume Buddhism to scientific rationality.

\section{TWO NON-EXCEPTIONALIST BUDDHIST MODERNISMS}

The first is the Buddhist modernism of the Chinese monk Taixu. Taixu was one of the Buddhist reformers (though perhaps it is more accurate to call him a "revolutionary" or a "radical") in China in the early twentieth century who attempted to develop a humanistic and politically engaged form of Buddhism capable of addressing the challenges of modernity. ${ }^{19} \mathrm{He}$ combined elements of East Asian Buddhism, largely Chan and Pure Land Buddhism, influenced also by Marxism and other radical Western philosophies, to reinterpret and reinvent Mahāyāna rituals and practices and Buddhist soteriology for political and utopian purposes. ${ }^{20}$

Taixu's Buddhism was intentionally syncretic and ecumenicist. It drew liberally from various Buddhist sects, all of which he deemed to be legitimate ways to the same destination. ${ }^{21}$ Taixu's Buddhism aimed at the creation of something new-a "rearticulation of the shared world" and a "rearticulation of the project of all humankind" (Gordon 2014, 3-4, 15, 79, 195) - in response to the social and spiritual problems of modernity: on the social level, capitalism and imperialism; but on a deeper spiritual level, the craving and grasping that underlies materialism and the desire for war. While "[s]ocialism has been proposed as a means to cure the evils of capitalism, and anarchism as an antidote to Imperialism", Taixu is quoted as saying, "these 'isms' have been worked out by minds which have not been perfectly free from the three basic evils:

\footnotetext{
${ }^{19}$ It might be most accurate to say that figures like Taixu break the Western disjunction between reformist and revolutionary. One might call him a transformationist. Like a revolutionary, Taixu believed that total transformation of fundamental sociocultural institutions and of the self was necessary. Like a reformist, however, he argued against violence as a means of transformation, for violence cannot properly transform the self, and in favor of gradualism over a revolutionary break, because selftransformation takes time. The relation between certain trends in Black liberationist thought and engaged Buddhism is relevant here. See Luk 2018 and Kalmanson 2012.

${ }^{20}$ Our exegesis in this section draws heavily on Pittman 2001 and Ritzinger 2017. The English language literature on Taixu is fairly limited. See Jones 2021a.

21 "Upāya (fangbian) has many gates, but in returning to the origin (gui yuan), there are not two roads." Taixu as quoted in Pittman 2001, 88.
} 
Avarice, Hate, and Lust.... Any remedy or means of cure for the present troubled world worked out by minds which are not yet perfectly free from such evils will tend only to increase the troubles instead of checking or preventing them" (Tai-hsü 1925, 387-8; quoted in Pittman 2001, 109-10). Taixu's soteriology was a "this-worldly soteriology", one that sought to "build ... the pure land on Earth" (Pittman 2001, 294). ${ }^{22}$

This soteriology involved, for Taixu, spiritual change by individuals (Ritzinger 2017, Ch. 2). Against the dominant Pure Land tradition in China, which held that Buddhism was essentially other-worldly and human action useless, focusing instead on praying to the Amitābha Buddha for aid and for a better rebirth, Taixu argued for a form of enlightenment through practicing right action, through various forms of meditation (though Taixu himself engaged seriously in meditative practice only in the earlier part of his life and did not emphasize it as the sole or even as the main method of achieving enlightenment), and through compassion for others and the world. ${ }^{23}$ Unlike many Buddhist reformers, however, Taixu was not critical of "superstitious" rituals or practices such as petitionary prayer, celestial buddha worship, or ancestor worship. He saw these rituals and practices as means of cultivation of self and community, as ways of developing the Ten Virtues and consequently fostering forms of right action, and as spiritually and directly contributing to the establishment of the pure land on Earth. ${ }^{24}$

This spiritual change involved the dispelling of the illusions of materialistic cravings and a recognition of causal interdependence and emptiness, allowing for the flourishing of one's inherent buddha-nature of other-oriented compassion and love. To spell out Taixu's theology in sufficient depth and detail would take us too far afield. But the point is that Taixu's modernist reinterpretation of Buddhist traditions did not single out one particular concept or practice (say, "mindfulness" or "awakening") and, through abstracting it from the conceptual web of which it was a part, resituate it in a reductionist and scientistic worldview. Rather, Taixu attempted to reinterpret the entire web through bringing it into conversation with other traditions and worldviews (Western radicalism and socialism, for instance). In doing so, Taixu created something creolized that was not simply one or another tradition, but an attempt to grapple with complex contemporary problems - exactly the kind of thing a cosmopolitan conversation should be doing.

Finally, Taixu engaged with (what he knew of) modern Western science in this similarly creolizing and cosmopolitan mode. Given his socialist diagnosis of the ills of modernity, Taixu was skeptical of the technologizing attitude and the scientistic pride that often accompanied scientific practice. He was, in that sense, anti-scientistic, and

\footnotetext{
${ }^{22}$ Taixu's conception of utopia drew on his invocations of Buddhist cosmologies, particularly those of Uttarakuru, the continent of plenty north of Mount Meru. See Jones 2021b; Pittman 2001, 223; and Ritzinger 2017, 81 .

${ }^{23}$ This is not to say that Pure Land Buddhism does not have its own potentials, precisely because of its passivity and downplaying of human agency and its metaphysics of value. See Kalmanson 2017.

${ }^{24}$ As Ritzinger (2017) details, Taixu adopted and made central to his theology the worship of Maitreya, the future Buddha, in part to resist the Pure Land worship of Amitābha and in part because Maitreya represented the more active and this-worldly revolutionary focus of Taixu's form of Buddhism.
} 
given his commitment to interdependence and a certain form of idealism, he was antireductionist and anti-materialist (Pittman 2001, Ch. 5, especially 246ff). For Taixu, "[t]he scientist claims that scientific knowledge is the whole truth and stops there. In this he resembles the blind man who, after examining the body of an elephant, declared the ear to be a fan and the tail a broom" (Taixu 1928, 48; quoted in Pittman 2001, 166). ${ }^{25}$ Scientism was a superstition: "there is one obstinate superstition among scientists, and that is, they believe this scientific method is the only road for arriving at truth, and fail to realize that the ultimate reality of this universe cannot be penetrated by it" (Taixu as quoted in Tsu 1933, 450-1; see also Pittman 2001, 167).

Yet Taixu was not dismissive of science, at least in the broad sense that term was given in early twentieth-century China, as a reliable empirical method of generating knowledge and understanding coupled with an open-minded and verificationist attitude representative of modernity. He stated thus: "Science itself is a method which is beyond criticism. Science is always open-minded, ready to discard what is disproved and to adopt what is verified, in order to reach the truth of reality" (Taixu as quoted in Tsu 1933, 450; see also Pittman 2001, 167). Indeed, Taixu was part of a group of thinkers and scientists in China in the early twentieth century - not all Buddhists-who were engaged in rethinking what was meant by "science" in light of, for example, classical Buddhist logic (Hammerstrom 2015; see also Ganeri 2021). There was the potential in this encounter for science as well as for Buddhism to be transformed.

Having said all this, it is not as if Taixu had been the perfect model for conversations between Buddhism and science. He manifested a tendency, due in part to a lack of understanding of science and in part to a broader form of Buddhist exceptionalism, to take what Thompson, following Francisco Varela, calls a "justificatory" attitude toward science. A "justificatory" attitude cherry-picks certain scientific conclusions to validate what one's own tradition holds to be true (Thompson 2020, 180). ${ }^{26}$ And Taixu, for political reasons, was an exceptionalist about Buddhism's unique political and cultural potential among religions to bring peace to the world because of its commitments to egolessness and compassion. Nonetheless, Taixu's Buddhist modernism provides a striking example of a non-scientistic Buddhist modernism that puts engagement with modern science in service of a larger cosmopolitan political ethics.

The second form of Buddhist modernism we will close with here is that of Vietnamese monk and activist Thich Nhat Hanh. We will be briefer here and just note again Nhat Hanh's syncretism and ecumenicism and his rethinking of Buddhist traditions for the soteriological purpose of enlightening this world. What we want to focus on in Nhat Hanh's thinking is again the non-scientistic rethinking of entire conceptual webs for this-worldly soteriological purposes, embedded in a wider metaphysics of nature and value.

\footnotetext{
${ }^{25}$ Taixu's Lectures in Buddhism (1928) was republished in Zhou 1957.

${ }^{26}$ So, for example, the Buddha prefigured Darwinian evolution and Copernican astronomy, and discovered microbes using his superhuman senses. See Taixu, "Buddhism and Science" (1923); extracted in Scott 2019 and Salguero 2019, 87-93. See also Hammerstrom 2015, Ch. 3.
} 
In his commentaries on the Heart Sūtra and elsewhere, Nhat Hanh develops the concept of causal interdependence, along Madhyamaka lines, into what he calls "interbeing". Everything that is, he argues, is only in coexistence with everything else: "'To be' is to inter-be. You cannot just be by yourself alone. You have to inter-be with every other thing" (Nhat Hanh 2011, 370; see also Aitken 2021). Nhat Hanh uses this concept to rethink the doctrines of karma and rebirth. ${ }^{27} \mathrm{We}$ "inter-are" with everything else, both in the sense that what we are now depends on all other things and in the sense that the compositional elements of what we are now were once parts of other things. As Nhat Hanh observes, "in the past I have been a cloud, a river, and the air.... This is not a question of belief in reincarnation. This is the history of life on Earth" (Nhat Hanh 2011, 423). There is no birth or death, as the Heart Sūtra says, only, for Nhat Hanh, change and transformation. And since we are - that is, since we "inter-are" with - all these other things, including other people and parts of institutions and systems, the karmic effects of our actions are reflected in all those other things as well. "Coming home to roost" makes different sense when the locus of the roosting is everything.

Nhat Hanh draws on this interconnected rethinking of these concepts and this nondualistic expansion of the self to include everything to develop a global sense of ethical responsibility, a cosmic compassion. This compassion is, as in Taixu, a spiritual and cultural response to the problems of modernity. Modern alienation comes from our ontological sense of separation from the Earth (Nhat Hanh 2013, 5). But Nhat Hanh's reinterpretation of rebirth means that we are the Earth and his reinterpretation of karma means that our actions continue the cycle of suffering but, if purified, could end it. As Nhat Hanh puts it:

Every thought we produce, everything we say and do, is an action. These actions continue forever. They can transform, but ... they will not disappear. We have to recognize the power of our karma and make a firm determination to be mindful of our thoughts, speech, and actions in order to heal ourselves and the Earth. (Nhat Hanh 2013, 72)

Grasping the meanings of causal interdependence and interbeing, appreciating the laws of karma and rebirth, and being mindful of one's thoughts, speech, and actions are means toward the soteriological ending of suffering.

Nhat Hanh makes very clear how his theology rests on an idealist Buddhist metaphysics, one that is neither reductively naturalist nor supernaturalist. He contrasts his idealism, according to which "there is mind and there are objects of mind, and ... they manifest at the same time," with "classical science", which "is based on the belief that there is an objective reality that exists even if the mind does not" (Nhat Hanh 2013, 11). In this metaphysics, there are no transcendent supernatural deities, but rather an immanent flow that is the divine:

${ }^{27}$ Compare McMahan 2008, 177: "Nhat Hanh's rethinking of karma and rebirth shows how the elaboration of one concept-interdependence - can exert a magnetic pull on others, reconfiguring the significance of a whole cluster of ideas and practices." See also the exchanges between Thompson (2021) and Finnigan (2021) and between Thompson (2020) and Lele (2020). 
God is on Earth, inside every living being. What we call the "divine" is none other than the energy of awakening, of peace, of understanding, and of love, which is to be found not only in every human being, but in every species on Earth.... The Earth herself has Buddha nature, therefore all her children must have Buddha nature, too. (Nhat Hanh 2013, 18)

Nhat Hanh relocates divinity from the transcendent realm of devas and other deities to the immanent realm of nature. Our participation in the divine is to be found in the connection among earthly entities.

These views are distinctively modernist even if they have precedents in classical Buddhism. David L. McMahan claims that Nhat Hanh's version of Buddhist modernism and similar versions bear-indeed require-Western influences, particularly those of European Romanticism and American Transcendentalism (McMahan 2008, 178-9), though one may think there are similar views that had arisen in Japan from the mixing of Buddhism, Daoism, and Shintoism even before D. T. Suzuki reshaped and refashioned Zen employing ideas from these Euro-American cultural and intellectual movements (Thompson 2020, 27).

Whatever the genealogy may be, such whole-cloth reimaginings of webs of key Buddhist concepts and practices, while they do abstract away from the deep historical contexts that Thompson would have us refer to, are not (at least not simply) rereadings of those concepts that impose a wholly distinct framework onto them. They are not imperialistic in the sense that underlies Thompson's cosmopolitan demand for deep historicism and contextualism. Indeed, they are articulated in response to various contemporary forms of imperialism and to the privileging of scientific rationality over all other forms of engagement with the world, rapacious capitalism over more communal and compassionate ways of living together, and human selfishness over the environment. They are ways of responding to modernity that resist certain common modernist tropes characteristic of the worldview that Thompson himself pushes back against. In that sense, these reimaginings might be understood as forms of what Casey R. Collins calls contramodernism: "a framework for living within secular modernity while consciously resisting, rejecting, reconfiguring, or subverting certain aspects of mainstream modernities without opposing modernism altogether" (Collins 2020, 58). Taixu and Nhat Hanh, in particular, provide examples of creolizing Buddhist modernists who rethink traditions by combining them with resources from other ways of thinking and being in order to address complex global problems.

Thompson is correct, in our view, to argue that predominant forms of Buddhist modernism are problematically exceptionalist in a scientistic sense and that buying into that larger framework robs Buddhism of much of its critical bite. Traditions and practices and the larger sociocultural contexts of ideas are important and conversation is impoverished when they are ignored. Nonetheless, the cosmopolitan response to that problem need not be, though it may well be, a form of deep historicism and contextualism that emphasizes understanding ideas in their original settings. It can be an intentional creolizing methodology that sees itself as creating something familiar but also new and distinctive by drawing liberally on whatever resources are available, unbound by false norms of purity and authenticity. Through two examples of this kind 
of Buddhist modernism, we have sketched what the cosmopolitan potentials of that methodology might be - potentials that are, we hope, in the cosmopolitan and humanist spirit of Thompson and his work.

\section{ACKNOWLEDGEMENTS}

We would like to thank Nhi Huynh, Donna Jarrett, Vivian Nguyen, Lucas Guimarães Pinheiro, Jeff Richey, Brent Robbins, Abraham Velez de Cea, and Caylee Weintraub for their helpful comments and suggestions on an earlier draft. Special thanks to the Editor-in-Chief of Comparative Philosophy, Bo Mou, for his tremendous support and encouragement during the writing process. Parts of this essay are adapted from our previous work (Nguyen and Hominh 2021) and we are grateful to The APA Newsletter on Asian and Asian American Philosophers and Philosophies for the permission to adapt our work for this publication. Thanks to Evan Thompson for taking the time to write a formal published reply to our piece.

\section{REFERENCES}

Abeysekara, Ananda (2019), "Protestant Buddhism and 'Influence': The Temporality of a Concept", Qui Parle 28.1: 1-75. <https://doi.org/10.1215/10418385-7522565>

Aitken, Allison (2021), "No Unity, No Problem: Madhyamaka Metaphysical Indefinitism", Philosophers' Imprint 21.31: 1-24

Appiah, Kwame Anthony (2007), Cosmopolitanism: Ethics in a World of Strangers (New York: W. W. Norton \& Company).

Clasquin-Johnson, Michel (2017), "Buddhism in Africa", in Michael Jerryson (ed.), The Oxford Handbook of Contemporary Buddhism (New York: Oxford University Press), 349-66.

Clasquin-Johnson, Michel, and Krüger, J. S. (eds) (1999), Buddhism and Africa (Pretoria: Department of Religious Studies, University of South Africa).

Collins, Casey R. (2020), "Buddhist Contramodernism: Reconfigurations of Tradition for Modernity", Journal of Global Buddhism 21: 51-69. $<$ http://dx.doi.org/10.5281/zenodo.4030975>

Elder, Linda, and Paul, Richard (1998), "Critical Thinking: Developing Intellectual Traits", Journal of Developmental Education 21.3: 34-5.

Federman, Asaf (2009), "Literal Means and Hidden Meanings: A New Analysis of Skillful Means", Philosophy East and West 59.2: 125-41.

Finnigan, Bronwyn (2021), "On Being a Good Friend to Buddhist Philosophy", APA Newsletter on Asian and Asian American Philosophers and Philosophies 20.2: 1518.

Ganeri, Jonardon (2021), "Buddhism after Buddhist Modernism: Comments on Evan Thompson's Why I Am Not A Buddhist", APA Newsletter on Asian and Asian American Philosophers and Philosophies 20.2: 18-21. 
Garfield, Jay L. (2021), "Throwing out the Buddha with the Offering Water: Comments on Evan Thompson's Why I Am Not a Buddhist", APA Newsletter on Asian and Asian American Philosophers and Philosophies 20.2: 21-6.

Glasgow, Joshua; Haslanger, Sally; Jeffers, Chike; and Spencer, Quayshawn (2019), What Is Race?: Four Philosophical Views (Oxford: Oxford University Press).

Gombrich, Richard F. (2009), Buddhist Precept and Practice: Traditional Buddhism in the Rural Highlands of Ceylon (New York: Routledge).

Gombrich, Richard, and Obeyesekere, Gananath (1988), Buddhism Transformed: Religious Change in Sri Lanka (Princeton, NJ: Princeton University Press).

Gordon, Jane Anna (2014), Creolizing Political Theory: Reading Rousseau Through Fanon (New York: Fordham University Press).

Grotius, Hugo (1625), De Iure Belli ac Paci Libri Tres, trans. Francis W. Kelsey with the collaboration of Arthur E. R. Boak, Henry A. Sanders, Jesse S. Reeves, and Herbert F. Wright (1925), The Law of War and Peace (New York: Bobbs-Merrill).

Guerrero, Laura P. (2021), "Free to Be You and Me: Cosmopolitanism, Pluralism, and Buddhist Modernism", APA Newsletter on Asian and Asian American Philosophers and Philosophies 20.2: 26-9.

Hammerstrom, Erik J. (2015), The Science of Chinese Buddhism: Early TwentiethCentury Engagements (New York: Columbia University Press).

Harding, John S.; Hori, Victor Sōgen; and Soucy, Alexander (2020), "Introduction: Alternate Buddhist Modernities", Journal of Global Buddhism 21: 1-10. $<$ http://dx.doi.org/10.5281/zenodo.4030971>

Harris, Elizabeth J. (2006), Theravāda Buddhism and the British Encounter: Religious, Missionary and Colonial Experience in Nineteenth-Century Sri Lanka (London: Routledge).

Ilaiah, Kancha (1996), Why I Am Not a Hindu: A Sudra Critique of Hindutva Philosophy, Culture and Political Economy (Calcutta: Samya).

Jeffers, Chike (2013a), “Appiah's Cosmopolitanism”, Southern Journal of Philosophy 51.4: 488-510.

Jeffers, Chike (2013b), "The Cultural Theory of Race: Yet Another Look at Du Bois's "The Conservation of Races", Ethics 123.3: 403-26.

Jeffers, Chike (2019), “Cultural Constructionism”, in Joshua Glasgow, Sally Haslanger, Chike Jeffers, and Quayshawn Spencer, What Is Race?: Four Philosophical Views (Oxford: Oxford University Press), 38-72.

Jones, Charles B. (2021a), “Taixu”, in Oxford Bibliographies Online (Oxford: Oxford University Press). < doi: 10.1093/obo/9780195393521-0260>

Jones, Charles B. (2021b), Taixu's 'On the Establishment of the Pure Land in the Human Realm': A Translation and Study (London and New York: Bloomsbury).

Kachru, Sonam (2021), "Some Questions for Friends of Buddhism", APA Newsletter on Asian and Asian American Philosophers and Philosophies 20.2: 29-32.

Kalmanson, Leah (2012), "Buddhism and bell hooks: Liberatory Aesthetics and the Radical Subjectivity of No-Self", Hypatia: A Journal of Feminist Philosophy 27.4: 810-27. <https://doi.org/10.1111/j.1527-2001.2011.01224.x> 
Kalmanson, Leah (2017), "Pure Land Ecology: Taking the Supernatural Seriously in Environmental Philosophy", in J. Baird Callicott and James McRae (eds), Japanese Environmental Philosophy (Oxford: Oxford University Press), 29-46.

Kant, Immanuel (2006), Toward Perpetual Peace and Other Writings on Politics, Peace, and History, ed. Pauline Kleingeld, trans. David L. Colclasure, with essays by Jeremy Waldron, Michael W. Doyle, and Allen W. Wood (New Haven, CT: Yale University Press).

Lele, Amod (2020), "An Index to the Thompson-Lele Correspondence", Love of All Wisdom: Philosophy Through Multiple Traditions (blog), June 4, 2020, $<$ http://loveofallwisdom.com/blog/2020/06/an-index-to-the-thompsonlelecorre spondence/>.

Lopez, Donald S. (2012), The Scientific Buddha: His Short and Happy Life (New Haven, CT: Yale University Press).

Luk, Sharon (2018), “'Sea of Fire': A Buddhist Pedagogy of Dying and Black Encounters across Two Waves", Souls: A Critical Journal of Black Politics, Culture, and Society 20.3: 267-88. <https://doi.org/10.1080/10999949.2018. $1521691>$

Macarthur, David (2019), "Liberal Naturalism and the Scientific Image of the World", Inquiry: An Interdisciplinary Journal of Philosophy 62.5: 565-85.

McGarrity, Andrew (2009), "Using Skilful Means Skilfully: The Buddhist Doctrine of Upāya and Its Methodological Implications", Journal of Religious History 33.2: 198-214. <doi: 10.1111/j.1467-9809.2009.00794.x>

McMahan, David L. (2008), The Making of Buddhist Modernism (Oxford: Oxford University Press).

Nguyen, A. Minh (2012), "Study Abroad's Contribution to Critical Thinking and World Citizenship", Think: Philosophy for Everyone 11.31: 27-40.

Nguyen, A. Minh (2013), "Transformation Through Study Abroad: Critical Thinking and World Citizenship", in Mary Kay Mulvaney and Kim Klein (eds), Preparing Tomorrow's Global Leaders: Honors International Education (Lincoln, NE: National Collegiate Honors Council), 21-43.

Nguyen, A. Minh, and Hominh, Yarran (2021), "Editors' Introduction: Buddhist Modernism and Its Discontents", APA Newsletter on Asian and Asian American Philosophers and Philosophies 20.2: 1-5.

Nhat Hanh, Thich (2011), Awakening of the Heart: Essential Buddhist Sutras and Commentaries (Berkeley, CA: Parallax Press).

Nhat Hanh, Thich (2013), Love Letter to the Earth (Berkeley, CA: Parallax Press).

Nussbaum, Martha C. (1996), "Reply", in Martha C. Nussbaum, For Love of Country: Debating the Limits of Patriotism, ed. Joshua Cohen (Boston: Beacon Press), 1356.

Paul, Richard (2008), The Thinker's Guide to the Nature and Functions of Critical and Creative Thinking (Dillon Beach, CA: Foundation for Critical Thinking).

Paul, Richard, and Elder, Linda (2005), Critical Thinking: Tools for Taking Charge of Your Learning and Your Life, $2^{\text {nd }}$ ed. (Upper Saddle River, NJ: Prentice Hall). 
Paul, Richard, and Elder, Linda (2009), The Miniature Guide to Critical Thinking: Concepts and Tools, $6^{\text {th }}$ ed. (Tomales, CA: Foundation for Critical Thinking).

Pittman, Don A. (2001), Toward a Modern Chinese Buddhism: Taixu's Reforms (Honolulu: University of Hawai'i Press).

Pollock, Sheldon (2006), The Language of the Gods in the World of Men: Sanskrit, Culture, and Power in Premodern India (Berkeley, CA: University of California Press).

Prothero, Stephen R. (1996), The White Buddhist: The Asian Odyssey of Henry Steel Olcott (Bloomington, IN: Indiana University Press).

Pye, Michael (2003), Skilful Means: A Concept in Mahayana Buddhism, $2^{\text {nd }}$ ed. (London: Routledge).

Rawls, John (2001), Justice as Fairness: A Restatement, ed. Erin I. Kelly (Cambridge, MA: Harvard University Press).

Rawls, John (2005), Political Liberalism, $2^{\text {nd }}$ ed. (New York: Columbia University Press).

Ritzinger, Justin (2017), Anarchy in the Pure Land: Reinventing the Cult of Maitreya in Modern Chinese Buddhism (New York: Oxford University Press).

Rocha, Cristina (2005), Zen in Brazil: The Quest for Cosmopolitan Modernity (Honolulu: University of Hawai'i Press).

Russell, Bertrand (2004), Why I Am Not a Christian and Other Essays on Religion and Related Subjects (London and New York: Routledge).

Salguero, C. Pierce (ed.) (2019), Buddhism and Medicine: An Anthology of Modern and Contemporary Sources (New York: Columbia University Press).

Scheffler, Samuel (1999), "Conceptions of Cosmopolitanism”, Utilitas 11.3: 255-76.

Schroeder, John W. (2001), Skillful Means: The Heart of Buddhist Compassion (Honolulu: University of Hawai'i Press).

Scott, Gregory Adam (2019), "Buddhism and Biomedicine in Republican China: Taixu's 'Buddhism and Science' (1923) and Ding Fubao's Essentials of Buddhist Science (1920)", in C. Pierce Salguero (ed.), Buddhism and Medicine: An Anthology of Modern and Contemporary Sources (New York: Columbia University Press), 87-93.

Tai-hsü (1925), "Rev. Tai-hsü’s Address", Eastern Buddhist 3.4: 387-8.

Taixu (1928), Lectures in Buddhism (Paris: Les Amis du Bouddhisme).

Thompson, Evan (2014), Waking, Dreaming, Being: Self and Consciousness in Neuroscience, Meditation, and Philosophy (New York: Columbia University Press).

Thompson, Evan (2020), Why I Am Not a Buddhist (New Haven, CT: Yale University Press).

Thompson, Evan (2021), "Replies to Critics", APA Newsletter on Asian and Asian American Philosophers and Philosophies 20.2: 41-55.

Tsu, Yu-Yue (1933), "Trends of Thought and Religion in China Today", The Open Court 47: 433-52.

Tweed, Thomas A. (2011), "Theory and Method in the Study of Buddhism: Toward 'Translocative' Analysis”, Journal of Global Buddhism 12: 17-32. 
Varela, Francisco; Thompson, Evan; and Rosch, Eleanor (2016), The Embodied Mind: Cognitive Science and Human Experience, rev. ed. (Cambridge, MA: MIT Press).

Vasquez, Manuel A. (2008), "Studying Religion in Motion: A Networks Approach", Method \& Theory in the Study of Religion 20.2: 151-84.

Velez de Cea, Abraham (2021), "Deconstructing Buddhist Modernism Without Postmodern Orientalism?", APA Newsletter on Asian and Asian American Philosophers and Philosophies 20.2: 34-8.

Warraq, Ibn (1995), Why I Am Not a Muslim (Amherst, NY: Prometheus Books).

Williams, Louise (2021), "Buddhist Modernism: Let's Be Suspicious But Not Because It Lacks Faith", APA Newsletter on Asian and Asian American Philosophers and Philosophies 20.2: 38-41.

Zhou, Xiangguang (1957), T'ai Hsu: His Life and Teachings (Allahabad, India: IndoChinese Literature Publications). 